Article

\title{
Antioxidant Properties of Synthesized Bicyclic Thiazolopyrimidine Derivatives as Possible Therapeutic Agents
}

\author{
Darinka Gjorgieva Ackova ${ }^{1, *,+}$ (D) Jelena Kotur-Stevuljevic ${ }^{2,+}$, Chandra Bhushan Mishra ${ }^{3}$, \\ Pratibha Mehta Luthra ${ }^{3}$ and Luciano Saso ${ }^{4}$ (D) \\ 1 Department of Pharmacy, Faculty of Medical Sciences, University Goce Delčev-Štip, R. Krste Misirkov \\ No. 10-A, POB 201, 2000 Štip, Macedonia \\ 2 Department for Medical Biochemistry, Faculty of Pharmacy, University of Belgrade, Studentski trg 1, \\ 11000 Belgrade, Serbia; jelena.kotur@pharmacy.bg.ac.rs \\ 3 Neuropharmaceutical Laboratory Dr. BR Ambedkar Center for Biomedical Research University of Delhi, \\ Delhi 110007, India; pmlsci@yahoo.com (C.B.M.); pmlsci@yahoo.com (P.M.L.) \\ 4 Department of Physiology and Pharmacology "Vittorio Erspamer", Sapienza University of Rome, \\ str. Aldo Moro 5, 00185 Rome, Italy; luciano.saso@uniroma1.it \\ * Correspondence: darinka.gorgieva@ugd.edu.mk; Tel.: +389-75-499-809 \\ + Authors contributed equally to this work.
}

Received: 9 December 2018; Accepted: 22 December 2018; Published: 29 December 2018

\begin{abstract}
Oxidant/antioxidant imbalance in the body has been implicated as one of the pathophysiological mechanisms leading to disease development. Therefore, we searched for a good antioxidant candidate that can be used as a therapeutic agent alone or in combination with other reported drugs. Earlier, we reported the $A_{2 A}$ receptor antagonist properties of 7-Imino-3-substituted-2-thioxo-3,7-dihydro-2H-thiazolo[4,5-d]pyrimidin-6-yl)-urea derivatives (compounds 1-12) and the neuroprotective effect of compound 2. Therefore, in the present work, the antioxidant potential of compounds 1-12 was studied. Compounds 1-12 were screened using different (red/ox) tests, such as the Ferric Reducing Antioxidant Power (FRAP) assay, to determine total antioxidant activity, redox status tests (with and without prooxidants) such as Advanced Oxidation Protein Products (AOPP) and Total Oxidative Status (TOS) which measures $\mathrm{H}_{2} \mathrm{O}_{2}$ and lipid hydroperoxides, Paraoxonase-1 Enzyme Activity (PON1), Total SH-groups content, and Total Antioxidative Status (TAS) for antioxidant determination. The Prooxidative Score, Antioxidative Score, and Oxy Score were also calculated. From the obtained results, compounds 6 (8720 FRAP value and 39.31 Oxy Score) and 12 (7866 FRAP value and 36.41 Oxy Score) were found to possess significant antioxidant activity with reasonable potential for therapeutic activity.
\end{abstract}

Keywords: thiazolopyrimidine derivatives; reactive oxygen species; antioxidant potential; redox-tests

\section{Introduction}

Reactive Oxygen Species (ROS) have a role in cell signaling, including apoptosis, gene expression, and activation of cell signaling cascades and they also have the potential to cause a number of deleterious events in the cells [1]. In normal aerobic cells, enzymatic (glutathione peroxidase, catalase, and superoxide dismutase) and non-enzymatic (antioxidants a-tocopherol, ubiquinone, beta-carotene, ascorbate, and glutathione) antioxidant systems are those that maintain a balance between oxidative damage and/or antioxidant protection of the cells. Insufficient antioxidant protection and/or excessive production of ROS generate oxidative stress, which has an important role in the development of cancers, aging, and many other diseases [2,3]. Oxidative damage and mitochondrial dysfunction contribute to 
the cascade of events leading to degeneration, for example, of the dopaminergic neurons (supported by postmortem brain analyses) which show increased levels of by-products of lipid peroxidation and DNA and RNA oxidation products [4]. Oxidative stress can be effectively neutralized by enhancing cellular defenses by applying higher levels of antioxidants [5].

Thiazoles are an important class of chemical compounds based on a simple five-membered heterocyclic ring. Due to its already known pharmacological activity, a lot of research studies have been done with different thiazole analogues to find possible agents with potential therapeutic use. The main and the most evaluated effects are antioxidant, anti-inflammatory, antimicrobial, antifungal, antiviral, diuretic, neuroprotective, and antitumor and cytotoxic potential [6-12]. This multiple effects of thiazole derivatives are due to a broad spectrum of pharmacological activities with priority to the following: (1) modulators of nicotinic, glutamate, cannabinoid and/or G protein-coupled receptors; (2) ligands of dopamine and histamine-3 receptors; (3) agonists of the $\gamma$-aminobuteric acid receptor and sphingosine-1-phosphate receptor [13].

Because thiazoles are core in the structure of a number of drug formulations, and because of the high potential for pharmacological activity, where, for our work, presumed antioxidant properties evoke specific interest, the present study is dedicated to the assessed antioxidant effect of synthesized bicyclic thiazolopyrimidine derivatives. These compounds are of great importance as potential therapeutic agents alone or in combination with reported drugs in the attenuation of neurological disorders. There are already studies that declared them as potent $A_{2 A}$ receptor antagonists [14-18] particularly, the 2-thioxo-thiazolo-pyrimidine derivatives, which not only showed a remarkable potential as $A_{2 A}$ receptor antagonists [16] but also exhibited a neuroprotective effect $[19,20]$. The $C-2$ of the 2-thioxothiazole ring of thiazolopyrimidine sandwiched between the heteroatoms sulfur and nitrogen and the exocyclic sulfur at C-2 may act as electron sinks. The 2-thioxothiazole ring of thiazolopyrimidines seemed to resemble to the 2-oxo-furon ring of ascorbic acid. This property gives thiazolopyrimidines potential for antioxidant activity.

In a number of neurological diseases an imbalance in the body of oxidants/antioxidants is detected as one of the mechanisms with pathophysiological importance for disease development, therefore, the main goal of our study was to find if some of investigated compounds could be good antioxidant candidates.

Evaluation was made by using different (red/ox) tests, namely, the Ferric Reducing Antioxidant Power (FRAP) assay which determines the total antioxidant activity of the sample; redox status tests (with and without prooxidants) such as: Advanced Oxidation Protein Products (AOPP) and Total Oxidative Status (TOS) which measures $\mathrm{H}_{2} \mathrm{O}_{2}$ and lipid hydroperoxides; for antioxidant determination evaluation was made using: Paraoxonase-1 Enzyme Activity (PON1), Total sulfhydryl (SH)-groups content, and Total Antioxidative Status (TAS, test for all reducing substances in plasma). Finally, summary scores, Prooxidative Score, Antioxidative Score, and Oxy Score were calculated.

\section{Materials and Methods}

\subsection{Chemicals and Instrumentation}

Solvents and reagents, unless otherwise specified, were of analytical reagent grade purchased from Aldrich Chemie (Steinheimm, Germany), Merck (Darmstadt, Germany), Chem Service (West Chester, PA, USA) and Santa Cruz Biotechnology (Dallas, Texas, USA). Analysis was performed by using a microplate reader (ChemWell, Awareness Technology, Inc., Palm City, FL, USA) and ILAB 300+ automatic analyzer (IL, Milan, Italy).

\subsection{Chemical Synthesis of the Bicyclic Thiazolopyrimidine Derivatives}

The chemical synthesis of the compounds was carried out according to the previous method [16]. Briefly, the reaction of the equimolar mixture of isothiocyanate, malononitrile and sulfur powder in dimethylformamide (DMF) was carried out and the addition of triethylamine (TEA) after 
15 min gave 4-amino-3-substituted-2-thioxo-2,3-dihydro-thiazole-5-carbonitrile derivatives that on refluxing in toluene with triethylorthoformate (equimolar ratio) and $p$-toluene sulfonic acid (catalytic amount) yielded imino-ether derivatives. The reaction of imino-ether derivatives with semicarbazide hydrochloride/furoic acid hydrazide (equal mol) and TEA (catalyst) in ethanol led to the compounds (1-12).

\subsection{Evaluation of the Antioxidant Potential of the Bicyclic Thiazolopyrimidine Derivatives}

\subsubsection{FRAP Analysis}

Total antioxidant activity was measured using the FRAP assay of Benzie and Strain [21]. The FRAP assay uses antioxidants as reductants in a redox-linked colorimetric method, employing an easily-reduced oxidant system present in stoichiometric excess. At low $\mathrm{pH}$, the reduction of ferric tripyridyltriazine (Fe III TPTZ) complex to ferrous form (which has an intense blue color) can be monitored by measuring the change in absorption at $593 \mathrm{~nm}$. All samples are prepared as solutions in dimethyl sulfoxide (DMSO) with the concentration $1 \mathrm{mg} / \mathrm{mL}$. The sample is mixed with FRAP reagent and the absorbance $\left(593 \mathrm{~nm}\right.$ ) is measured at the end-point after incubation at $37^{\circ} \mathrm{C}$ for $30 \mathrm{~min}$. The total antioxidant status is expressed as $\mu \mathrm{mol} \mathrm{FeSO}_{4} \mathrm{~L}^{-1}$. All values are means of triplicate analyses $\pm \mathrm{SD}$.

\subsubsection{Redox Status Methods}

Analyses were performed in the human serum pool harvested from healthy volunteers. Investigated compounds dissolved in DMSO in volume of $50 \mu \mathrm{L}$ were added in serum aliquots $(450 \mu \mathrm{L})$ in duplicates. Three different concentrations were prepared $(100 \%, 50 \%, 25 \%)$ for every substance. An additional set of samples was prepared with the addition of the prooxidant terc-bythil hydroperoxide (TBH) in order to get information about the antioxidative potency of the compounds. The samples were incubated at $37^{\circ} \mathrm{C}, 2 \mathrm{~h}$ in a water bath. The control sample was native serum pool.

\section{Advanced Oxidation Protein Products (AOPP)}

AOPP was assayed in $20 \mathrm{mM}$ phosphate buffer with $\mathrm{pH} 7.4$ in reaction with glacial acetic acid and $1.16 \mathrm{M}$ potassium-iodide according to Witko-Sarsat et al., [22]. The complex formed has an absorbance maximum at $340 \mathrm{~nm}$. The calibration of this reaction is performed with Chloramine $\mathrm{T}$ as a standard, with a concentration range 10-100 $\mu \mathrm{mol} / \mathrm{L}$. This compound also has a specific absorption maximum at $340 \mathrm{~nm}$. From the obtained parameters, the Oxy Score is calculated that represents the resulting action and is then used for further analysis.

Total Oxidative Status (TOS)

TOS was measured by using a spectrophotometric method optimized by Erel, 2005 [23], and Kotur-Stevuljevic et al., 2015 [24]. All oxidants such as hydrogen-peroxide and lipid-hydroperoxide from the sample have the capability to oxidize the ferrous ion-o-dianisidine complex to a ferric ion. The reagent is composed of $5 \mathrm{mM}$ ferrous ammonium sulfate and $10 \mathrm{mM} o$-dianisidinedihydrochloride. The oxidation is performed in high concentration of glycerol molecules $(1.35 \mathrm{~mol} / \mathrm{L})$. The second reaction is based on the ferric ion reaction with xylenol orange $(150 \mu \mathrm{mol} / \mathrm{L})$ in an acidic medium, which makes a colored complex. The intensity of color is proportional to the total amount of oxidant molecules present in the sample. Absorbance measurement is at $560 \mathrm{~nm}$. The assay is calibrated with hydrogen peroxide (water solution, 10-200 $\mu \mathrm{mol} / \mathrm{L}$ ) and the results are expressed in micromolar hydrogen peroxide equivalent per liter $\left(\mu \mathrm{mol} \mathrm{H}_{2} \mathrm{O}_{2}\right.$ equiv/L).

\section{Paraoxonase-1 Enzyme Activity (PON1)}

Serum PON1 activity was measured kinetically using paraoxon (POase activity) and diazinon-O-analog (DZOase activity) as substrates, by the method of Richter and Furlong, 1999 [25], and the PON1 phenotype was determined both graphically and by using the anti-mode method with 
DZOase/POase activity ratio calculation. POase activity determination is based on serum PON1 enzyme activity on $1.2 \mathrm{mM}$ paraoxon as a substrate, and its conversion to a $p$-nitrophenol compound; the rate of this conversion could be followed at $405 \mathrm{~nm}$, because in alkaline conditions $(10 \mathrm{mmol} / \mathrm{L}$ Tris- $\mathrm{HCl}, \mathrm{pH}$ 8.5, $2 \mathrm{mmol} / \mathrm{L} \mathrm{CaCl}_{2}$ ) $p$-nitrophenol has an intense yellow color. DZOase activity was measured upon PON1 enzyme reaction with a diazinone-O-analog $(1 \mathrm{mM})$; after that it decomposed on diethyl-phosphate and 2-isopropyl-4-methyl-6-pyrimidinol (IMHP); the rate of this conversion could be followed at $270 \mathrm{~nm}$, where IMHP has a characteristic absorption maximum.

\section{Total SH-groups Content}

The levels of SH-groups were measured by Ellman's method [26] modified by Kotur-Stevuljevic et al., 2015 [24], using $10 \mathrm{mM}$ dinitrodithiobenzoic acid (DTNB) as a reagent. DTNB reacts with aliphatic thiol compounds in a basic environment $(\mathrm{pH} 9.0)$ and this reaction generates 1 mole $p$-nitrophenol anion per mole of thiol. The absorbance was measured at $412 \mathrm{~nm}$. The calibration of the method was achieved with the reduced glutathione in the concentration range from $0.1-1.0 \mathrm{mM}$.

Total Antioxidative Status (TAS)

TAS was measured by a spectrophotometric method using $10 \mathrm{mmol} / \mathrm{L}$ 2,2'-azino-bis(3ethylbenzothiazoline-6-sulphonic acid (ABTS) as a chromogen [27]. The reduced ABTS molecule is oxidized to $\mathrm{ABTS}^{+}$radical cation using hydrogen peroxide in acidic medium (an acetate buffer 30 mmol/L, $\mathrm{pH}$ 3.6). Under defined conditions, emerald green $\mathrm{ABTS}^{+}$molecules are stable for a long time. The antioxidants present in the sample cause reagent discoloration to a degree proportional to their concentrations and the discoloration rate is directly related to the antioxidative potential of the sample. The reaction is calibrated with Trolox, a water-soluble vitamin E analog, the measurement is performed at $660 \mathrm{~nm}$, and the assay results are expressed in micromoles Trolox equivalent/L.

Prooxidative Score, Antioxidative Score, and Oxy Score

Oxy Score is the difference between Prooxidative Score (average value of $Z$ Scores of all measured prooxidants and their products) and Antioxidative Score (average value of $Z$ Scores of all measured antioxidants). A larger Oxy Score means worse redox status (weaker antioxidative protection, higher prooxidants content).

$\mathrm{Z}$ Score is the difference between the original value and the control value divided by SD of control values (or population means and SDs).

\subsection{Statistics}

The statistical analysis was made by ANOVA using the simple difference between all 12 substances, in a whole group (all concentrations and with and without added TBH as an prooxidant) and then in subgroups according to TBH status (with or without), and also using repeated measures ANOVA because we performed analysis on the same material (the same serum pool from healthy donors) so we could think about samples as the same samples under different study conditions.

\section{Results}

\subsection{Advanced Oxidation Protein Products (AOPP)}

Amino acids, peptides, and proteins are vulnerable to attacks by a variety of free radicals and related oxidants. Oxidation of particularly sensitive amino acid residues, aggregation, cross linking, fragmentation, as well as loss of enzymatic or other functional properties are a few of the documented examples. In this study, we investigated the effect of the compounds 1-12 on normal plasma samples as advanced oxidation protein products (AOPP), and found its slight prooxidative effects more in compounds 1-6 and 12, and less in compounds 7-11. The prooxidative effects were also noticed in samples with TBH and in vitamin E samples. It seems that protein biomolecules are the first line of 
defence from radical species, possibly like some kind of free radical buffers, because of their ubiquity $(p<0.001$ for compound 6 vs. pure serum pool).

\subsection{Total Oxidative Status (TOS)}

The total oxidative status is a chemical measure of the prooxidative medium potency measured by $\mathrm{H}_{2} \mathrm{O}_{2}$ and lipid hydroperoxide activity. We reported here a significantly higher TOS concentration in compounds 1-3 (among which compound 3 had the highest value) compared to the plain serum pool and the pool with vitamin E dissolved $(p<0.05,<0.01$ respectively).

\subsection{Paraoxonase-1 Enzyme Activity (PON1)}

Regarding PON1 antioxidative activity, all substances showed significant prooxidative activity, specifically anti-PON1 activity, i.e., all substances cause significant fall in its enzymatic activity, maybe through the $\mathrm{pH}$ change or some other chemical influence in the reaction milieu $(p<0.01$ for all compounds compared to the native serum pool, except compound 9).

\subsection{Total SH-Groups Content}

Total sulfhydryl groups content is a marker of the reductive capability of biological fluids (blood). It is obvious that almost all 12 substances caused SH-groups content increase, but this is especially true for compounds 8 and $9(p<0.01$ compared to the native pool).

\subsection{Total Antioxidative Status (TAS)}

The general antioxidative potency of the serum pool was enlarged in the presence of compounds 1-6 and 12, compared to the native serum, as was the case with serum with TBH ( $p<0.001$ vs. native pool for 1-6 and 12th compounds).

\subsection{FRAP Assay Together with Final Oxy Score}

The obtained results from the FRAP assay, together with the final Oxy Score, are presented in Table 1. The table also contains the structural formulae and molecular weight of all compounds for a more clear presentation. The results from the tests for oxidative stress status parameters (with and without the addition of prooxidant TBH) are presented in Figure 1.

Table 1. FRAP assay and Oxy Score values.

No


Table 1. Cont.

\begin{tabular}{|c|c|c|c|c|c|}
\hline No & Structural Formulae & $\begin{array}{c}\text { MW } \\
\left(\mathrm{g} \cdot \mathrm{mol}^{-1}\right)\end{array}$ & $\begin{array}{l}\text { FRAP Values } \\
\begin{array}{c}\left(\mu \mathrm{mol}_{\mathrm{L}} \mathrm{L}\right. \\
\left.\text { FeSO }_{4}\right) \\
(p=0.01)\end{array}\end{array}$ & $\begin{array}{c}\text { OXY SCORE } \\
\text { Median } \\
\text { (25th-75th } \\
\text { Percentile) }\end{array}$ & $\begin{array}{c}\text { Significant } \\
\text { Difference vs. }\end{array}$ \\
\hline 4 & & 282 & $1140 \pm 0.2$ & $\begin{array}{c}44.54 \\
(32.02-48.85)\end{array}$ & $\begin{aligned} & 3 \\
(p= & 0.043)\end{aligned}$ \\
\hline 5 & & 318 & $7580 \pm 0.0$ & $\begin{array}{c}42.49 \\
(37.08-46.85)\end{array}$ & / \\
\hline 6 & & 443 & $8720 \pm 0.11$ & $\begin{array}{c}39.31 \\
(34.36-52.03)\end{array}$ & $\begin{array}{c}3 \\
(p=0.006)\end{array}$ \\
\hline 7 & & 332 & $1052 \pm 0.1$ & $\begin{array}{c}45.23 \\
(39.46-49.31)\end{array}$ & $\begin{array}{c}3 \\
(p=0.013)\end{array}$ \\
\hline 8 & & 321 & $405 \pm 0.18$ & $\begin{array}{c}46.43 \\
(20.71-50.69)\end{array}$ & $\begin{array}{c}3 \\
(p=0.001)\end{array}$ \\
\hline 9 & & 335 & $394 \pm 0.12$ & $\begin{array}{c}52.21 \\
(38.17-65.57)\end{array}$ & / \\
\hline 10 & & 349 & $130 \pm 0.37$ & $\begin{array}{c}47.30 \\
(36.92-55.38)\end{array}$ & $\begin{array}{c}3 \\
(p<0.001)\end{array}$ \\
\hline 11 & & 333 & $272 \pm 0.11$ & $\begin{array}{c}32.41 \\
(18.31-54.88)\end{array}$ & $\begin{array}{c}1 \\
(p=0.024)\end{array}$ \\
\hline 12 & & 369 & $7866 \pm 0.05$ & $\begin{array}{c}36.41 \\
(34.29-37.87)\end{array}$ & $\begin{array}{c}1 \\
(p=0.012)\end{array}$ \\
\hline
\end{tabular}

* Oxy Score of controls: Control serum pool-36.00 (35.45-36.80), significant difference vs. 1, 2, 3 ( $p<0.01$ for all three), TBH $(p<0.01)$; serum pool with TBH-74.50 (73.75-75.20), significant difference vs. vitamin $\mathrm{E}(p<0.001)$; serum pool with vitamin E-14.15 (13.72-15.62), significant difference vs. 1, 2, 3, TBH ( $p<0.001$ for all). 

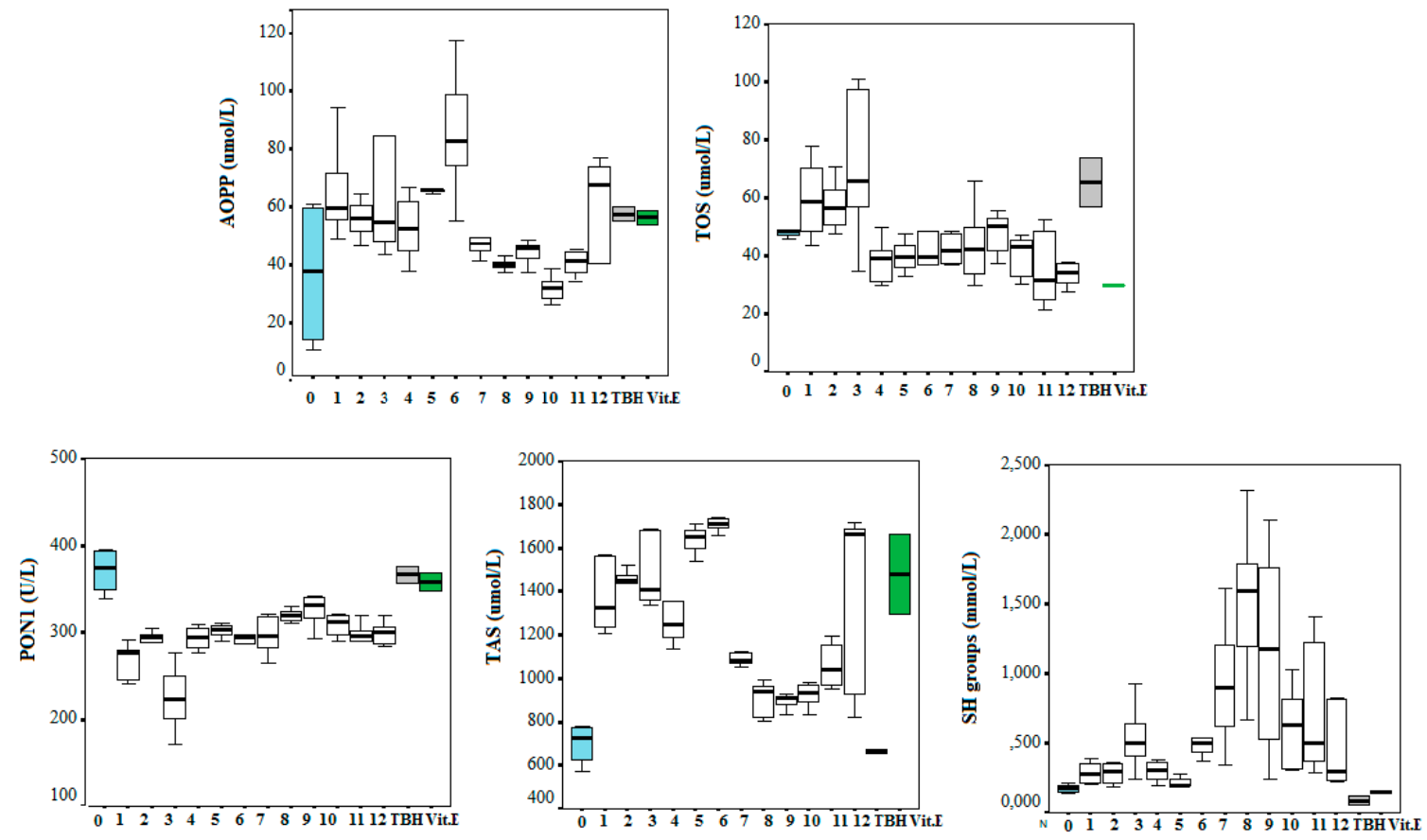

Figure 1. Oxidative stress status parameters after the addition of the tested compounds numbered from 1-12. Blank serum pool is signed as 0 (blue box); TBH-serum pool with prooxidant substance terc-buthyl-hydroperoxide (grey box) and serum pool with vitamin $\mathrm{E}$ as antioxidative substance (green box).

\section{Discussion}

The interpretation of the results and the evaluation of the antioxidant potential of the tested compounds were done with respect to their chemical structures and the principles and mechanisms of the used test reactions. According to the molecular structure, all compounds possess general thiazolopyrimidine pharmacophore with two different main modifications, where compounds 1-7 are with a urea moiety, and compounds 8-12 incorporate a furonamide moiety. In addition, different substituents on the $\mathrm{N}$-atom in the thiazole ring are present in all compounds. There are studies that present increased water solubility properties in thiazolopyrimidine derivatives with the urea and furonamide substituents [16].

The antioxidant mechanism of the FRAP assay is based only on $\mathrm{e}^{-}$transfer. According to the obtained FRAP values, the highest total antioxidant activity in the group of compounds with urea moiety can be found with compound 6 , followed by compound 5 . Concerning the structure-activity relationship, we find the benzene substituent on the $\mathrm{N}$-atom in the thiazole ring as important for antioxidant activity. Moreover, incorporation of an iodine atom in the benzene ring as electron withdrawing group in compound 6 additionally increases the antioxidant potential. A well-known fact is that the halogen atom (iodine in this case) is hydrophobic and will have influence on general physic-chemical properties of the molecule as well as propagation of the diffusion across the biological membranes in the body. Having in mind these findings, we presume the presence of a hydrophobic substituent at benzene ring as a valuable positive factor for the highest antioxidant activity. In the study of Desai et al. from 2016 [10], the presence of a hydrophobic substituent in the molecule was connected with the high antimicrobial potential of the studied substances. In their case, they make a positive relationship between the presence of a fluoro and/or nitro group as a substituent in 1,3,5-triazine based thiazole derivatives and antimicrobial activity against a set of microorganisms.

Connecting the structure/activity data, we find that a direct bond between the $\mathrm{N}$-atom and benzene ring in the molecule is probably of great importance, because beside the fact that compounds 5 and 7 have almost the same structure, the presence of only one $-\mathrm{CH}_{3}$ group between two rings 
decreases 7-8 folds the antioxidant activity in compound 7 . The status of compound 6 as the substance with the best antioxidant potential from the group with a urea moiety also confirms the obtained parameters for the oxidative stress status and the value for the Oxy Score (39.31).

Among compounds that incorporate a furonamide moiety, compounds 11 and 12 possess the highest antioxidant activity (Oxy Score 32.41 and 36.41, respectively). Compound 12 also has the highest value from the FRAP test (7866). Some authors $[16,28]$ connected the presence of a furan ring in the structure of non-xanthine analogues as essential for the binding of the molecule with the active site of $A_{2 A}$ receptors, which proposes a potential for a pharmacological effect in neurological disorders (e.g., Parkinson disease). However, this kind of an electron-rich group is prone to oxidative metabolism and after metabolic reactions they can be transformed into a potential reactive metabolite [29].

From Table 1, it can be seen that the FRAP values showed that four out of the seven thiazolopyrimidines with a urea moiety i.e., compound 6 (8720), >5 (7580), >3 (7328), >2 (5228), and compound 12 (7866) between five thiazolopyrimidines with a furonamide moiety, possesses significant antioxidant activity values. The Oxy Score is the difference between the Prooxidative Score and the Antioxidative Score. A larger Oxy Score means a worse redox status (weaker antioxidative protection, higher prooxidants content). The Oxy Score of twelve compounds ranged from 32.41 (compound 11) to 74.32 (compound 3). Moreover, we found that the thiazolopyrimidines with a urea moiety possessed a higher Oxy Score range; $74.32\left(3, \mathrm{C}_{4} \mathrm{H}_{9}\right), 72.45\left(1, \mathrm{C}_{2} \mathrm{H}_{5}\right), 67.25\left(2, \mathrm{C}_{3} \mathrm{H}_{7}\right)$, $45.23\left(7, \mathrm{CH}_{2} \mathrm{Ph}\right) 44.54\left(4, \mathrm{C}_{3} \mathrm{H}_{5}\right), 42.49(5, \mathrm{Ph}), 39.31$ (6, Ph(p-I)), thus indicating that, although thiazolopyrimidines with a urea moiety apparently seem to possess a significant antioxidant potential, thiazolopyrimidines with a furanamide moiety possess a better Oxy Score $\left(52.21\left(9, \mathrm{C}_{3} \mathrm{H}_{7}\right), 47.30\right.$ $\left.\left(10, \mathrm{C}_{4} \mathrm{H}_{9}\right), 46.43\left(8, \mathrm{C}_{2} \mathrm{H}_{5}\right), 36.41(\mathrm{Ph}, 12), 32.41\left(11, \mathrm{C}_{3} \mathrm{H}_{5}\right)\right), 32.41$ being the best Oxy Score for $\mathrm{N}_{3}$-allyl-2-thioxo-thiazolopyrimidine furanamide. Concerning the fact that Oxy Score values depend on several factors, the structure/activity relationship (SAR) of 12 compounds for Oxy Score illustrated that in both thiazolopyrimidine series, a saturated N-substitution showed a higher Oxy Score as compared to unsaturated/conjugated N-substitution. The best antioxidant values and their related Oxy Scores in decreasing order of arrangement were found for compound $12((7866 ; 36.41)>6(8720$; $39.31)>5(7580 ; 42.49)>2(5228 ; 67.25)>3(7328 ; 74.32))$.

Compounds $6(8720 ; 39.31)$ and $12(7866 ; 36.41)$ were found to possess the best antioxidant potential among the series of twelve thiazolopyrimidines. Incidentally, compound 12 also shows strong binding affinity $(\mathrm{K} 1=0.0085 \pm 0.001 \mathrm{nM})$ with A1 receptors and activated cyclic adenosine monophosphate (cAMP) at low concentrations $(0.048 \mathrm{pmol} / \mathrm{mL})[16]$.

\section{Conclusions}

Through results obtained from in vitro screening of selected thiazolopyrimidine derivatives, we have confirmed that some representatives such as compounds $6(8720 ; 39.31)$ and $12(7866 ; 36.41)$ exhibited a remarkable antioxidant potential. The studied compounds presented hereby significantly differ in their corresponding antioxidant activity. The main reason is the type of substituents. Accordingly, particularly derivatives possessing electron withdrawing groups (halogen atom) or electron-rich groups (furan ring) were identified as compounds with a potent antioxidant capability. Concerning the values obtained, substances 6 and 12 have the best antioxidant capability. Thus, these chemical entities may be considered suitable candidates for further investigation/development as possible effective antioxidant agents.

Author Contributions: Conceptualization, D.G.A., P.M.L. and L.S.; Formal analysis, J.K.-S.; Investigation, D.G.A., J.K.-S. and C.B.M.; Methodology, D.G.A., J.K.-S., C.B.M. and P.M.L.; Resources, L.S.; Supervision, P.M.L. and L.S.; Validation, J.K.-S.; Visualization, D.G.A.; Writing-original draft, D.G.A.; Writing-review \& editing, D.G.A., C.B.M., P.M.L., J.K.-S. and L.S.

Funding: This research received no external funding.

Conflicts of Interest: The authors declare no conflict of interest. 


\section{References}

1. Hancock, J.T.; Desikan, R.; Neill, S.J. Role of Reactive Oxygen Species in Cell Signaling Pathways. Biochem. Soc. Trans. 2001, 29, 345-349. [CrossRef] [PubMed]

2. Motor, S.; Ozturk, S.; Ozcan, O.; Gurpinar, A.B.; Can, Y.; Yuksel, R.; Yenin, J.Z.; Seraslan, G.; Ozturk, O.H. Evaluation of total antioxidant status, total oxidant status and oxidative stress index in patients with alopecia areata. Int. J. Clin. Exp. Med. 2014, 7, 1089-1093. [PubMed]

3. Gupta, R.K.; Patel, A.K.; Shah, N.; Chaudhary, A.K.; Jha, U.K.; Yadav, U.C.; Gupta, P.K.; Pakuwal, U. Oxidative stress and antioxidants in disease and cancer: A review. Asian Pac. J. Cancer P 2014, 15, 4405-4409. [CrossRef]

4. $\quad$ Butterfield, D.A.; Reed, T.; Newman, S.F.; Sultana, R. Roles of Amyloid $\beta$-Peptide-Associated Oxidative Stress and Brain Protein Modifications in the Pathogenesis of Alzheimer's Disease and Mild Cognitive Impairment. Free Radic. Biol. Med. 2007, 43, 658-677. [CrossRef] [PubMed]

5. Nimse, S.B.; Pal, D. Free radicals, natural antioxidants, and their reaction mechanisms. RSC Adv. 2015, 5, 27986. [CrossRef]

6. Kalkhambkar, R.G.; Kulkarni, G.M.; Shivkumar, H.; Rao, N. Synthesis of novel triheterocyclicthiazoles as anti-inflammatory and analgesic agents. Eur. J. Med. Chem. 2007, 10, 1272-1276. [CrossRef]

7. Abu-Hashem, A.A.; Youssef, M.M.; Hussein, H.A.R. Synthesis, antioxidant, antitumor activities of some new thiazolopyrimidines, pyrrolothiazolopyrimidines and triazolo-pyrrolothiazolopyrimidines derivatives. J. Chin. Chem. Soc.-Taip. 2011, 58, 41-48. [CrossRef]

8. Bano, T.; Kumar, N.; Dudhe, R. Free rsdical scavenging properties of pyrimidine derivatives. Org. Med. Chem. Lett. 2012, 2, 34. [CrossRef]

9. Jaishree, V.; Ramdas, N.; Sachin, J.; Ramesh, B. In vitro antioxidant properties of new thiazole derivatives. J. Saudi Chem. Soc. 2012, 16, 371-376. [CrossRef]

10. Desai, N.C.; Makwana, A.H.; Rajpara, K.M. Synthesis and study of 1,3,5-triazine based thiazole derivatives as antimicrobial agents. J. Saudi Chem. Soc. 2016, 20, S334-S341. [CrossRef]

11. Liaras, K.; Fesatidou, M.; Geronikaki, A. Thiazoles and thiazolidinones as COX/LOX inhibitors. Molecules 2018, 23, 685. [CrossRef] [PubMed]

12. Djukic, M.; Fesatidou, M.; Xenikakis, I.; Geronikaki, A.; Angelova, V.T.; Savic, V.; Pasic, M.; Krilovic, B.; Djukic, D.; Gobeljic, B.; et al. In vitro antioxidant activity of thiazolidinone derivatives of 1,3-thiazole and 1,3,4-thiadiazole. Chem.-Biol. Interact. 2018, 286, 119-131. [CrossRef] [PubMed]

13. Leoni, A.; Locatelli, A.; Morigi, R.; Rambaldi, M. Novel thiazole derivatives: A patent review (2008-2012. Part 2). Expert Opin. Ther. Pat. 2014, 24, 759-777. [CrossRef] [PubMed]

14. Helal, C.J.; Sanner, M.A.; Cooper, C.B.; Gant, T.; Adam, M.; Lucas, J.C.; Kang, Z.; Kupchinsky, S.; Ahlijanian, M.K.; Tate, B.; et al. Discovery and SAR of 2-aminothiazole inhibitors of cyclin-dependent kinase 5/p25 as a potential treatment for Alzheimer's disease. Bioorg. Med. Chem. Lett. 2004, 14, 5521-5525. [CrossRef] [PubMed]

15. Slee, D.; Lanier, M.; Vong, B.G.; Chen, Y.; Zhang, X.; Lin, E.; Moorjani, M.; Laria, J.C.C.P. Substituted pyrimidines as adenosine receptor antagonists. U.S. Patent US2008/0275064, 6 November 2008.

16. Luthra, P.M.; Mishra, C.B.; Jha, P.K.; Barodia, S.K. Synthesis of novel 7-imino-2-thioxo-3,7-dihydro-2Hthiazolo[4,5-d] pyrimidine derivatives as adenosine $\mathrm{A}_{2 \mathrm{~A}}$ receptor antagonists. Bioorg. Med. Chem. Lett. 2010, 20, 1214-1218. [CrossRef] [PubMed]

17. Luthra, P.M.; Mishra, C.B. Novel 3-substituted 7-imino-2-thioxo-3,7-dihidro-2H-thiazolo[4,5-dipyrimidin]-6-yl and process for preparation thereof. U.S. Patent US2012/0264937, 18 October 2012.

18. Mishra, C.B.; Kumari, S.; Tiwari, M. Thiazole: A promising heterocycle for the development of potent CNS active agents. Eur. J. Med. Chem. 2015, 92, 1-34. [CrossRef]

19. Kumari, N.; Agrawal, S.; Kumari, R.; Sharma, D.; Luthra, P.M. Neuroprotective effect of IDPU (1-(7-imino-3-propyl-2,3-dihydrothiazolo [4,5-d]pyrimidin-6(7H)-yl)urea) in 6-OHDA induced rodent model of hemiparkinson's disease. Neurosci. Lett. 2018, 675, 74-82. [CrossRef] [PubMed]

20. Franco, R.; Navarro, G. Adenosine $A_{2 A}$ Receptor Antagonists in Neurodegenerative Diseases: Huge Potential and Huge Challenges. Front. Psychiatry 2018, 9, 68. [CrossRef]

21. Benzie, I.F.F.; Strain, J.J. The ferric-reducing ability of plasma (FRAP) as a measure of "antioxidant power": The FRAP assay. Anal. Biochem. 1996, 239, 70-76. [CrossRef] 
22. Witko-Sarsat, V.; Nguyen, M.; Capeillere-Blandin, C.; Nguyen, A.T.; Zingraff, J. Advanced oxidation protein products as a novel marker of oxidative stress in uremia. Kidney Int. 1996, 49, 1304-1313. [CrossRef]

23. Erel, O. A new automated colorimetric method for measuring total oxidant status. Clin. Biochem. 2005, 38, 1103-1111. [CrossRef] [PubMed]

24. Kotur-Stevuljevic, J.; Bogavac-Stanojevic, N.; Jelic-Ivanovic, Z.; Stefanovic, A.; Gojkovic, T.; Joksic, J.; Sopic, M.; Gulan, B.; Janac, J.; Milosevic, S. Oxidative stress and paraoxonase 1 status in acute ischemic stroke patients. Atherosclerosis 2015, 241, 192-198. [CrossRef] [PubMed]

25. Richter, R.J.; Furlong, C.E. Determination of paraoxonase (PON1) status requires more than genotyping. Pharmacogenetics 1999, 9, 745-753. [CrossRef]

26. Ellman, G.I. Tissue sulfhydril groups. Arch. Biochem. Biophys. 1959, 82, 70-77. [CrossRef]

27. Erel, O. A novel automated direct measurement method for total antioxidant capacity using a new generation, more stable ABTS radical cation. Clin. Biochem. 2004, 37, 277-285. [CrossRef] [PubMed]

28. Richardson, C.M.; Gillespie, R.J.; Williamson, D.S.; Jordan, A.M.; Fink, A.; Knight, A.R.; Sellwood, D.M.; Misra, A. Identification of non-furan containing $A_{2 A}$ antagonists using database mining and molecular similarity approaches. Bioorg. Med. Chem. Lett. 2006, 16, 5996-5997. [CrossRef] [PubMed]

29. Langmead, C.J.; Andrews, S.P.; Congreve, M.; Errey, J.C.; Hurrell, E.; Marchall, F.H.; Mason, J.C.; Richardson, C.M.; Robertson, N.; Zhukov, A.; et al. Identification of Novel Adenosine A2A Receptor Antagonists by Virtual Screening. J. Med. Chem. 2012, 55, 1904-1909. [CrossRef]

(C) 2018 by the authors. Licensee MDPI, Basel, Switzerland. This article is an open access article distributed under the terms and conditions of the Creative Commons Attribution (CC BY) license (http://creativecommons.org/licenses/by/4.0/). 